\title{
MENINGKATKAN KEMAMPUAN PRA-MATEMATIKA DENGAN MENGGUNAKAN MEDIA BALOK CUISENAIRE PADA ANAK KELOMPOK A2 PAUD HAQIQI KOTA BENGKULU
}

\author{
Maya Lasuka \\ Mayalasuka@gmail.com \\ M. Nasirun \\ h.m.nasirun@gmail.com \\ Mona Ardina \\ mona.ardina@gmail.com
}

\begin{abstract}
This study aied to improve the pre-mathematics ability through the introduction to pattern activity and classification by using Cuisenaire block media on children of group A2 at Early Childhood Education Program (PAUD) of Haqiqi of Bengkulu City. The research method used in this study was Classroom Action Research (CAR) which was conducted through two cycles and each cycle consisted on three meetings. The subject of the study were as many as 9 students consisted of 5 male student and 4 female students. Data collection technique was done by using observation method. Data analysis was conducted by calculating the average score and learning mastery score. The result of the study revealed that there was improvement on pre-mathematic ability of the children through the introduction to pattern activity and classification with the average score of 4,3 and learning mastery of $86 \%$ categorized as very good criteria. It is suggested for the next research to use cuisenaire block as a media to measure other abilities with several aspect that need to be considered such as size and basic pattern.
\end{abstract}

Keywords: Pra-mathematics ability; cuisenaire block

\section{PENDAHULUAN}

Pra-matematika

merupakan kemampuan yang dapat dikuasai oleh seorang anak dalam menyelesaikan berbagai persoalan yang dihadapinya dalam kehidupan sehari-hari. Hal ini berkenaan dengan pola-pola, urutan, pengklasifikasian, ukuran, konsep, bilangan, korespondensi satu-satu, dan konsep bentuk geometri. Sedangkan menurut Suyanto (2005:160) pramatematika kegiatan untuk melatih anak mengontruksikan pemahaman dengan bahasa simbolik yang disebut sebagai abstraksi sederhana kemudian mengajarkan anak memahami konsep bilangan dan operasi bilangan.
Konsep dalam pra-matematika untuk anak usia dini yang harus dipahami oleh anak salah satunya adalah tentang pola. Pola (pattern) adalah menyusun rangkaian warna, bagian-bagian, benda-benda, ukuran, suara-suara dan gerakan-gerakan yang dapat diulang (Aisyah, 2008:5.34). Pola yang sangat perlu dikembangkan pada anak usia 4-5 tahun sesuai tingkat pencapaian perkembangan dalam Permendiknas no. 137 tahun 2014 pola abcabc. Indikator tingkat pencapaian perkembangan anak pada usia tersebut seharusnya anak sudah dapat memperkirakan urutan berikutnya setelah melihat bentuk 2 pola serta dapat meniru pola dengan berbagai bentuk. Anak dapat menyusun sebuah pola $A B C-A B C$ 
berdasarkan kriteria ataupun ciri tertentu, seperti: berdasarkan warna, ukuran, bentuk, dan sebagainya. Selain itu, pentingnya pengenalan pola berulang pada anak dimaksudkan agar anak mampu memperkirakan kejadian, peristiwa, maupun hal-hal pentingnya lain di kehidupannya dengan baik, contohnya: anak dapat memperkirakan pola waktu dalam satu hari. Perkiraan pola yang seharusnya dimengerti anak pada urutan pola waktu dalam satu hari adalah pagi, siang, lalu sore, dan terakhir adalah malam.

Selain pengenalan konsep pola, konsep pra-matematika yang harus dikembangkan pada anak usia dini adalah klasifikasi. Klasifikasi merupakan salah satu tahapan awal anak untuk belajar berpikir logis, yakni anak akan belajar mengenai aturan yang jelas dalam mengelompokkan benda pada saat mengklasifikasikan benda. Menurut Kennedy (2009:141) kemampuan klasifikasi tidak tumbuh begitu saja pada diri seseorang, namun perlu dibangun sejak dini. Anak sudah harus mulai diasah kemampuan klasifikasi dalam hal yang kongkrit . Misalnya dimulai dari melatih anak membereskan mainan berdasarkan jenis, ukuran, bentuk dan warna.

Penelitian dilakukan di PAUD Haqiqi Kota Bengkulu. Sebelum melakukan penelitian, peneliti melakukan observasi untuk mengetahui bagaimana tingkat kemampuan anak dalam mengenal pola dari yang sederhana yaitu pola $A B-A B$. Pada hasil observasi yang telah dilakukan kemampuan anak dalam mengenal pola sudah dalam kategori sangat tinggi. Sehingga kemampuan anak dalam mengenal pola berulang dapat ditingkatkan ke pola yang lebih kompleks lagi. Pengenalan pola yang dilakukan guru sampai dengan tahap ini adalah pola $A B C$ $A B C$ dan masih sering menggunakan lembar kerja dalam kegiatan pembelajarannya sehingga kurang efektif. Berdasarkan latar belakang diatas, peneliti ingin membuktikan apakah dengan menggunakan media balok cuisenaire dapat meningkatkan kemampuan pramatematika pada anak kelompok A2 di PAUD Haqiqi Kota Bengkulu.

Berdasarkan rumusan masalah tersebut, tujuan dari penelitian ini adalah untuk mengetahui peningkatan kemampuan pra-matematika dengan menggunakan balok cuisenaire pada anak kelompok A2 di PAUD Haqiqi Kota Bengkulu.

Sedangkan menurut Gunawan (2011:112) komponen pra-matematika pada anak meliputi : 1) klasifikasi, dalam kegiatan mengklasifikasi anak akan belajar tentang penggabungan dan intersection (potongan), 2) pola, menentukan pola dan menstrukturkan serta mengorganisasikan informasi merupakan proses matematika yang penting. Menyusun pola seperti: $a b a b$, abcabc, dan aabbaabb dapat dipelajari oleh anak usia dini, dan banyak anak di PAUD dapat melakukan lebih banyak pola yang lebih kompleks, 3) perbandingan, dengan mempelajari perbandingan anak akan memberika pertanyaan seperti mana yang lebih banyak, sama, dan mana yang lebih sedikit) mengajarkan mengenai konsep korespondensi satu-satu. 4) bilangan, 5) pengenal tentang operasi bilangan. Selanjutnya Smith (2006:36) menyebutkan bahwa komponen pra-matematika yaitu : mencocokkan, perbandingan, mengurutkan/seriasi, ruang dan bentuk, pola dan aljabar permulaan

Dalam penelitian ini peneliti hanya memfokuskan penelitian pada dua aspek pra-matematika yaitu aspek pengenalan pola dan klasifikasi.

Menurut Smith (dalam Suyanto, 2005: 170) pola adalah salah satu bentuk cara untuk mengurutkan sesuatu sesuai dengan urutannya. Salah satu cara untuk mengenalkan pola pada anak usia dini dengan bahan pola yang konkrit atau nyata, 
misalnya dengan kancing baju, buah, sayur, dan lain-lain.

Shamsudin (2002:106) menjelaskan secara rinci bahwa klasifikasi adalah kegiatan menyusun, memilih, mengumpulkan atau memisahkan suatu himpunan benda ke dalam beberapa himpunan yang lebih kecil berdasarkan atribut benda (ukuran, warna, bentuk) sehingga menjadi beberapa himpunan

Eliyawati (2005:69) mengemukakan bahwa George Cuisenaire menciptakan balok cuisenaire untuk mengembangkan kemampuan berhitung anak, pengenalan bilangan, dan untuk meningkatkan kemampuan anak dalam bernalar. Balok ini terdiri dari sepuluh buah balok yang menyerupai anak tangga.

\section{METODE}

Penelitian ini menggunakan jenis Penelitian Tindakan Kelas (PTK). Penelitian tindakan kelas adalah penelitian tindakan yang dilakukan oleh guru yang sekaligus sebagai peneliti dikelasnya atau bersama dengan orang lain (kolaborasi) dengan merancang,melaksanakan dan merefleksikan tindakan secara kolaboratif dan partisipasif yang bertujuan untuk memperbaiki atau meningkatkan mutu (kualitas) proses pembelajaran di kelasnya melalui suatu tindakan (Treatment) tertentu dalam suatu siklus (Kunandar, 2013:44-45).

Penelitian tindakan kelas ini dilakukan di PAUD Haqiqi Kota Bengkulu, dengan subjek penelitian yaitu anak kelompok $A 2$ yang berjumlah 9 anak terdiri dari 5 anak laki-laki dan 4 anak perempuan. Penelitian tindakan kelas ini dilakukan dengan menggunakan balok cuisenaire untuk meningkatkan kemampuan pramatematika. Penelitian ini dilakukan dalam II siklus, masing-masing siklus dilakukan sebanyak 3 kali pertemuan, setiap satu kali petemuan dilakukan observasi untuk mengetahui peningkatkan kemampuan pra-matematika pada anak. Penelitian ini dilaksanakan dari tanggal 21 Agustus 2017 sampai dengan 2 September 2017 dengan tahap perencanaan, pelaksanaan, pengamatan (observasi) dan refleksi. Indikator keberhasilan pada penelitian ini yaitu jika anak mencapai ketuntasan $75 \%$.

\section{HASIL DAN PEMBAHASAN}

Kemampuan pra-matematika anak meningkat dengan menggunakan media balok cuisenaire. Hal ini dapat dibuktikan dari nilai rata-rata pada setiap pertemuan. Pada siklus I rata-rata yang diperoleh yaitu 3.7 dengan kriteria cukup dan memperoleh presentase sebesar $74 \%$. pada siklus II meningkat dengan perolehan rata-rata mencapai 4,3 dengan kriteria baik dan memperoleh presentase $86 \%$.

Materi yang diberikan pada setiap pertemuan disesuaikan dengan tema dan sub tema. Adapun tema pada siklus I yaitu Lingkungan dengan sub tema rumahku. Sedangkan pada siklus II menggunakan tema lingkunganku dengan sub tema sekolah, jembatan dan taman bermain. Kegiatan pada siklus I dan II memiliki perbedaan pada tingkat kesulitan.

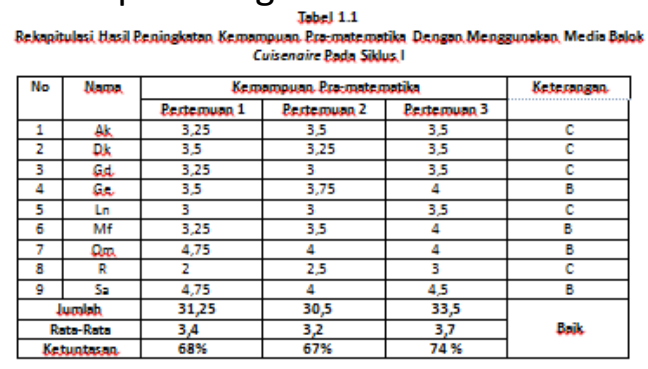

Pada siklus I pertemuan pertama dan kedua kemampuan pemecahan masalah anak mengalami penurunan dan meningkat lagi pada pertemuan ketiga. 


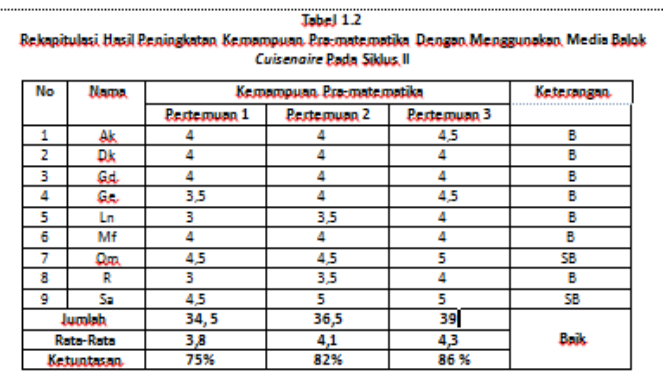

Sedangkan pada siklus II pertemuan pertama, kedua dan ketiga mengalami peningkatan pada kemampuan pramatematika anak. Pernyataan ini dapat dilihat dari hasil pengamatan aktivitas anak setiap pertemuan, baik secara klasikal maupun individual pada setiap siklus.

Penurunan hasil pada pertemuan kedua siklus I terjadi karena terdapat kelemahan, kelemahan tersebut diantaranya: 1) konsep pola yang dikenalkan setiap pertemuan memiliki tingkat kesulitan 2) terdapat beberapa anak yang masih ragu-ragu dan terbalik saat mengurutkan, 3) ada anak yang kurang tepat saat mengklasifikasi.

Kemampuan pra-matematika anak pada aspek mengurutkan pola memperoleh nilai rata-rata pada kriteria cukup. Pada awalnya anak berada kriteria kurang, ini dikarenakan pada siklus I anak-anak masih mengalami kesulitan dalam mengurutkan pola karena anak belum terbiasa dan belum memahami materi tentang pola walaupun sudah diberikan balok yang berwarna, padahal guru sudah menjelaskan dan mencontohkan urutan pola balok cuisenaire. Pada siklus I pertemuan kedua tiga anak mengalami penurunan setelah ditanyakan kepada anak ia mengalami kesusahan dengan pola pada pertemuan kedua, dan pada pertemuan ketiga siklus I semua anak mengalami peningkatan .

Pada siklus II ada perubahan dalam warna balok yang digunakan, pada siklus II ini balok yang digunakan ada balok cuisenaire dengan warna natural. Setelah diberi penjelasan dengan cara mengurutkan urutan pola dipapan tulis, anak-anak kembali mengurutkan pola, pada pertemuan pertama sudah sebagian anakanak sudah mendapat nilai dengan kriteria baik pada aspek ini, pada pertemuan kedua 2 (dua) anak telah mencapai kriteria sangat baik yaitu Qm dan Sa, 2 (dua) anak dengan kriteria baik, 4 (empat) dengan kriteria Cukup dan 1 (satu) orang anak dengan kriteria kurang yaitu R. Pada pertemuan ketiga siklus II semua anak telah mencapai nilai dengan kriteria baik pada aspek ini.

Kemampuan pra-matematika anak pada aspek kemampuan mengklasifikasi terbukti dapat meningkat melalui kegiatan pengenalan pola dengan menggunakan media balok cuisenaire. Hal ini terbukti dari semua subjek mengalami peningkatan dari kriteria kurang menjadi Sangat Baik, pada awalnya anak-anak masih mengalami kebingungan ketika mengklasifikasikan balok yang sesuai dengan ukurannya. Pada siklus I pertemuan pertama 1 (satu) anak mendapat nilai dengan kriteria Kurang yaitu $\mathrm{R}$, dan anak-anak yang lain mendapatkan nilai dengan kriteria Cukup. Pada pertemuan kedua dan ketiga anak-anak terus mengalami peningkatan.

Pada siklus II anak-anak terlihat bingung saat pengenalan balok natural, karena balok ini memiliki ukuran yang tidak terlalu jauh yaitu hanya $1 \mathrm{~cm}$ sehingga anak-anak membutuhkan waktu untuk mengenalnya. Agar anak tertarik dalam melakukan pembelajaran guru dapat melakukan hal berikut: 1) guru terlebih dahulu mengenalkan pola dengan hal-hal yang dekat dengan anak dan selalu mengenalkan ukuran disetiap awal pembelajaran, 2) mengkondisikan anak, 3) guru membuat suasana belajar yang menyenangkan, memberikan dan membangun rasa percaya diri anak agar anak tidak ragu-ragu dalam melakukan kegiatan pengenalan pola,4) membimbing anak sehingga anak dapat mengklasifikasikan balok. Pada pertemuan 
ketiga siklus II semua anak telah berada pada kriteria Baik. Dengan kata lain melalui kegiatan dengan menggunakan balok cuisenaire kemampuan anak pada aspek klasifikasi meningkat.

Dalam setiap pertemuan siklus I aspek yang menonjol pada kemampuan pra-matematika ini adalah aspek kemampuan mengklasifikasikan balok yang terus meningkat. Aspek klasifikasi merupakan hal lebih menyenangkan oleh anak. Anak dikatakan baik dalam aspek ini jika dapat mengelompokkan beberapa ukuran balok sesuai dengan instruksi harian. Sedangkan aspek yang memiliki peningkatan paling rendah adalah aspek mengurutkan pola. Hal ini dikarenakan anak masih sering terbalik dalam mengurutkan pola.

\section{KESIMPULAN}

1. Proses pembelajaran dengan menggunakan media balok cuisenaire dilakukan dengan berulang-ulang sehingga dapat meningkatkan kemampuan pra-matematika pada anak, dengan langkah pertama pada siklus I yaitu mengurutkan pola $A B C$ $A B C$ dan mengklasifikasikan balok sampai dengan tujuh balok yang memiliki ukuran yang sama. Sedangkan pada siklus II dengan langkah pertama yaitu mengurutkan pola $A B C D-A B C D$ dan mengklasifikasikan sepuluh balok yang memiliki ukuran yang sama.

2. Kemampuan pra-matematika anak dapat ditingkatkan dengan menggunakan media balok cuisenaire. Hal ini dapat dilihat pada siklus I ratarata nilai anak 3.7 dan ketuntasan belajar mencapai indikator $74 \%$, kemudian meningkat pada siklus ॥ rata-rata nilai anak 4,3 dan ketuntasan belajar mencapai indikator $86 \%$. Hasil tersebut menunjukkan bahwa pada setiap siklus kemampuan pramatematika anak meningkat yang berarti kegiatan dengan menggunakan media balok cuisenaire dapat meningkatkan kemampuan pramatematika pada anak.

\section{Saran}

1. Bagi peneliti

Untuk peneliti selanjutnya untuk dapat meningkatkan kemampuan pramatematika dalam aspek pengenalan pola berdasarkan bentuk, ukuran dan posisi bisa dilakukan bisa dilakukan dengan media yang serupa dengan balok cuisenaire seperti permaianan edukatif storting colours karena peneliti telah menggunakan balok cuisenaire dapat meningkatkan kemampuan pra-matematika. Media balok cuisenaire juga dapat dimodifikasi dengan menambahkan angka ataupun dengan beberapa gambar pada balok, dan menambahkan tulisan dalam bahasa inggris ataupun bahasa Indonesia guna meningkatkan kemampuan bahasa pada anak.

2. Bagi guru/pendidik

Media Balok cuisenaire dapat digunakan untuk meningkatkan kemampuan pra-matematika anak, guru dapat menggunakan media balok cuisenaire sebagai media pembelajaran untuk kelas $A$ tahun ajaran selanjutnya. Guru juga dapat mengembangkan balok cuisenaire dapat meningkatkan kemampuan motorik halus, bahasa dan pra-matematika pada anak.

\section{DAFTAR PUSTAKA}

Aisyah, Siti. 2008. Perkembangan Dan Konsep Dasar Pengembangan Anak Usia Dini. Jakarta: Universitas Bengkulu

Eliyawati, Cucu. 2005. Pemilihan dan Pengembangan Sumber Belajar. Jakarta. Direktorat Pembinaan Pendidikan 
Gunawan, Rudy. 2011. Pendidikan Filosofi, Konsep dan Aplikasi. Bandung: Alfabeta

Kennedy, Tipps Johnson.2008. Guiding Children's Learning Of Mathematics. America: Thomson Higher Education.

Kunandar. 2013. Penilaian Autentik. Jakarta: Raja Grafindo Persada

Peraturan Menteri Pendidikan dan Kebudayaan RI No.137 Tahun 2014 tentang Kurikulum 2013 Pendidikan Anak Usia Dini

Shamsudin, Baharin. 2002. Kamus Matematika Bergambar Untuk Sekolah Dasar. Jakarta: Grasindo

Smith. Susan Perry. 2006. Early Chilhood Mathematic. America: Pearson.

Suyanto, Slamet. 2005. Konsep Dasar Pendidikan Anak Usia Dini. Jakarta: Departemen Pendidikan Nasional 